\title{
Eväitä kasvatustieteen kriittiseen itseymmärrykseen
}

\author{
Saari, Antti 2011. Kasvatustieteen tiedontahto. Kriittisen historian näkökulmia \\ suomalaiseen kasvatuksen tutkimukseen. Kasvatusalan tutkimuksia 55. Jyväskylä: Suomen \\ kasvatustieteellinen seura. $461 \mathrm{~s}$.
}

Antti SaARen teos on filosofishistoriallinen analyysi suomalaisen kasvatustieteen historiasta 1900-luvun alusta 1970-luvulle. Aiemmista suomalaisen kasvatustieteen historian esityksistä (esimerkiksi Päivänsalo 1971; Iisalo 1980; Rinne \& Kivirauma 1997; Ahonen 2003) se poikkeaa tiukan teoreettisen näkökulmansa puolesta. Saari analysoi tutkimuksessaan empiirisen kasvatustieteen historiaa sen yhteiskunnallisten vaikutusten, ennen kaikkea vallan näkökulmasta. Tutkimuksen käsitteistö ja metodologia perustuvat Michel Foucault' $n$ genealogiaan, kriittiseen historiankirjoitukseen, missä tiedon ja vallan suhteen tarkastelu on keskiössä.

Historian tutkimuksessa aiheen valinta ja kysymyksen asettelu kumpuavat aina nykyisyydestä. Saaren motiivina onkin - kuten hän teoksen johdannossa tekee lukijalle selväksi - huolenaihe kasvatustieteen nykytilasta, jota leimaa hänen mukaansa välineellisyys, empiristisyys, psykologisuus sekä irtaantuminen kasvatuksen päämääriin liittyvien kysymysten tarkastelusta. Kirjoittajan huoleen voi monilta osin yhtyä, kun katsoo mihin tämän päivän kasvatustieteellinen tutkimus, yliopisto, tiede- ja koulutuspolitiikka ovat menossa.

Tutkimuksen pääongelmana on etsiä vastausta siihen, "millä tavoin suomalainen kasvatustiede pyrki tuottamaan objektiivista ja samalla kasvatuksen ja opetuksen käytäntöjen kannalta merkityksellistä ja hyödynnettävää tietoa" (s. 18). Pääongelmasta Saari johtaa Foucault' $n$ käsitteistön (tieto, tietävä subjekti ja valta) varassa kolme tarkentavaa tutkimuskysymystä.

\section{VIATTOMUUDEN KULISSIT}

Saaren tutkimuksen perimmäinen idea on se, että kasvatustieteen harjoittaminen ei ole ollut eikä ole viatonta. Tutkimuksessa todennetaan sitä, miten1900-luvun alussa muotoutunut ja toisen maailmansodan jälkeen valta-asemaan noussut empiirinen kasvatustiede on arvovapauden ja objektiivisuuden kulissien takana määritellyt totuuksia niin itsestään, tieteen mahdollisuudesta tavoittaa kohteensa, kasvatettavien perimmäisestä olemuksesta, koulusta opettajista opettamisesta kuin oppilaistakin. Näin se on osaltaan määritellyt sitä, miten oppilaita, koulua ja opettajan työtä on pyritty hallitsemaan.

Tutkimusaineisto perustuu tekstien analyysille, jotka koostuvat pääsääntöisesti suomenkielisistä kasvatusalan aikakauslehtiartikkeleista, tutkimusraporteis- 
ta ja oppikirjoista. Lähteet eivät suinkaan ole uusia ja tutkimattomia. Tutkimuksen ideana onkin ollut lukea niitä uudella tavalla, Foucault 'n kriittisen historiankirjoituksen hengessä.

Kirja on jäsennelty hiukan erikoisesti. Ensimmäiset 90 sivua kattavat johdantoluvun sekä luvun 2, jossa rakennetaan tutkimuksen foucault 'lainen teoriakehikko ja käsitteistö. Tämä jälkeen kirja jakaantuu kahteen osaa, joissa molemmissa on omat johdantolukunsa. Näin teos sisältää yhteensä kolme johdantolukua mikä sopinee filosofille.

Tutkimuksen ensimmäinen osa keskittyy kasvatustieteen historiallisen itseymmärryksen tarkasteluun yleisellä tasolla. Analyysissa osoitetaan perusteellisesti ja laajasti länsimaiden ihmistieteiden historian ja filosofisen perinteen yhteydet suomalaisen empiirisen kasvatustieteen muotoutumiseen. Saari todentaa muiden muassa sitä, miten yksilö kasvatustieteen tutkimuksen ja tiedon kohteena kumpusi biologiasta, fysiologiasta sekä varhaisesta psykologiasta. Niiden kautta kasvatustiede kietoutui tiukasti psykologiatieteen traditioon ja erityisesti behaviorismiin lähtiessään etsimään yksilöpsykologisista lähtökohdista oppimisen (tai koko elämänprosessiin) yleisiä lainalaisuuksia.

Osassa II edetään kohti suomalaisen kasvatustieteen historiallis-konkreettista tarkastelua. Ensimmäiseksi Saari analysoi sitä, miten käsitys oppimisesta ja sen "objektiivisesta" tutkimuksesta sikisi 1800-luvun jälkipuoliskon aistinfysiologisessa tutkimuksesta sekä varhaisesta henkisten toimintojen, kuten muistin kokeellisista tutkimuksista. Kokeellisen asetelman idea ei merkinnyt vain koeolosuhteiden kontrollointia, vaan tutkittavan (oppijan, oppilaan) ja tarkkailevan tutkijan (opettajan) kontrolloimista. Kokeellisen kasvatusopin juonteet huipentuivat 1960- ja 1970-luvuilla oppimisteknologian varhaismuotoihin, opetuskoneiden, ohjelmoidun opetukseen ja tavoiteoppimisen ja -taksonomioiden esiinmarsseihin.

\section{KOSKENNIEMEÄ JA VAHERVUOTA}

Mielenkiintoisena historiallisena tapauksena Saari esittelee yhden maamme tunnetuimman kasvatustieteilijän, Matti Koskenniemen tutkimuksia. Hänen jo 1930-luvulla alkaneet sosiaalisen vuorovaikutuksen tutkimuksensa ja hankkeensa huipentuivat 1970-luvulla Helsinki DPA-projektiin, jonka tavoitteena oli rakentaa objektiivinen ja kokonaisvaltainen opetuksen kuvailujärjestelmä. Yksittäisten oppilaiden tarkkailun ja diagnosoinnin lisäksi tiedon ja hallinnan kohteeksi nousivat monimutkaiset sosiaaliset vuorovaikutusprosessit, "sotkuinen hyörinä". Tutkimusten pyrkimyksenä oli tuottaa tietoa ja välineitä opettajalle objektiivisesti tarkkailla tuon kohinan takana piileviä säännönmukaisuuksia. Näin kokonaisesta koululuokasta muodostui kasvatustieteellisen tiedon ja hallinnan kohde.

Paljon ajattelun aihetta aikam- me arviointi- ja vertailuhegemonian näkökulmasta antavat kirjan IIosan alaluvut, jotka on oivaltavasti nimetty "Suurten lukujen tasavallaksi" ja "Arvioinnin valtakunnaksi”. Näissä Saari kuvaa, kuinka tilastotieto ja siihen perustuvat tekniikat pyrittiin valjastamaan koulun käytäntöjen hallinnan tarpeisiin, yksilöiden luokitteluun, arviointiin sekä normaaliuden ja poikkeavuuden määrittelyyn samoin kuin koko koulujärjestelmä kaiken kattavaan arviointiin - numeroilla hallintaan. Suorastaan henkeäsalpaavaa luettavaa ovat 1940-1950-luvuilla vaikuttaneen psykometriikan kehittelijän Toivo Vahervuo -sitaatit normaalijakaumaperiaatteiden perusteista ja niiden sovellusohjeista kouluarvosteluun.

\section{VALLAN MONITAHOINEN KUDELMA}

Tutkimuksen viides ja viimeinen luku on syvällinen pohtiva yhteenveto. Tyylilleen uskollisena ja filosofin varovaisuudella Saari välttää yksinkertaisten tulkintojen ja johtopäätösten tekemistä, mikä näkyy lukuisissa luonnehdinnoissa siitä, mitä tutkimuksella ei ole tavoiteltu. Tekijä kiteyttää ja todentaa uskottavasti oman analyysinsa pohjalta Foucatult 'n teorian keskeiset ideat tiedon ja vallan (hallinnan) ja subjektin keskinäissuhteiden monitahoisuudesta koulun historiassa; miten ne edellyttävät toinen toisiaan, miten valta on monimuotoinen kudelma suhteita ja strategioita, tekniikkoja ja tiedonmuodostusta, diskursiivisia käytäntöjä ja subjek- 
tien tuottamista. Saari myös ulottaa analyysinsa laajemmin yhteiskunnan hallinnan sfääreihin kuten elinikäiseen oppimiseen.

Yksi monista Saaren lopputulemista on se, että kasvatustiede on jatkuvassa liikkeessä tai epätäydellisyyden tilassa sen pyrkiessä paljastamaan tutkimuskohteestaan, ihmisestä sellaista (elämänprosessien kehityspotentiaaleja), mitä ei oikeastaan milloinkaan kyetä täydellisesti tavoittamaan. Se oikeuttaa itsensä jatkuvasti lupauksilla "paremmasta" tieteeseen perustuvasta hallinnasta. Kyse on jonkinlaisesta tiedon ja hallinnan oravanpyörästä:

"Näin paljastuu tapa, jolla tieto ajaa loputtomasti takaa itseään ja kääntää hallinnan ongelmanasetteluita tieteen kielelle, luoden itse ne ongelmat, jotka se pyrkii ratkaisemaan" (s. 422).

Vaikka Saari ei päädykään mihinkään "ei mitään uutta auringon alla” -päätelmiin, hän nostaa esiin sen, miten nykyaikainen kasvatustiede itse asiassa askaroi samojen ongelmien kanssa kuin vuosikymmeniä aikaisemminkin ja toistaa muiden muassa positivistista mittausmaniaansa Pisan ja muiden arviointien muodossa.

Mutta Saari ei kuitenkaan lankea perinteiseen yksioikoiseen positivismin parjaamiseen. Hänen mukaansa pyrkiessään irtautumaan spekulatiivisuudesta kasvatustiede itse asiassa tavoitteli niitä samoja asioita kuin tänäkin päivänä: jopa äärimmäisessä behaviorismissaan se pyrki voimakkaasti lapsi- ja nuorisokeskeisyy- teen ja otti tehtäväkseen yksilön elämänprosessien "salaisuuksien" tutkimisen pyrkien vapauttamaan myös opettajaa eri aikoina erilaisista kahleista. Tässä kuvastuu teoksen voima ja tekijänsä kypsyys tutkijana: Saari välttää visusti löytäneensä mitään uutta totuutta kasvatustieteen historiasta eikä pakota tulkintojaan väkisin teoriakehykseensä. Hän jättää monia kysymyksiä avoimeksi.

Teoksen viimeisillä sivuilla hän käsittelee kritiikin olemusta ja sen mahdollisuuksia ja myös sen ylevää tehtävää, joka hänen sanojensa mukaan on "kysymysten ja huolenaiheiden auki pitämistä" (s. 434) eikä sen tule olla "kyynistä epäilyä" vaan "eettistä kieltäytymistä lakata kysymystä" (s. 435, kirja päättyy). Siinäpä huoneentaulua itse kullekin.

\section{UHANALAINEN LAJITYYPPI}

Saaren tutkimus edustaa nykyään jo uhanalaista lajityyppiä. Se on painava ja paksu (korkeimmalla arvosanalla hyväksytty) kasvatustieteen monografiaväitöskirja, jonka syvällinen filosofis-historiallinen ote yltää niin tieteenfilosofian kuin tiedonsosiologiankin kentille. Sellaiselle lukijalle, joka ei ole perehtynyt Foucault' $n$ ajatteluun tai ei ole erityisemmin filosofisesti sivistynyt, lukeminen on paikoin hyvin vaativa urakka.

Vaikka kirja on erinomaiselle kielellä kirjoitettu ja loogisesti ylöspantu, ei kirjoittaja luonnollisestikaan ole voinut välttää Foucault'n ja muiden filosofien vaikeaa käsitteistöä. Paikoin teksti yltyy filosofiseksi jargoniksi. Mutta ken kirjan jaksaa ajatuksella lukea, hänen vaivansa kyllä palkitaan.

\section{Arto Jauhiainen}

kasvatustieteen professori

Turun yliopisto

\section{LÄHTEET}

Ahonen, S. (2003). Kasvatustiede. Teoksessa P. Tommila \& A. Korppi-Tommila (toim.) Suomen tieteen vaiheet. Helsinki: Yliopistopaino, 216-219.

lisalo, T. (1980). Spekulatiivisesta empiiriseen kasvatustieteeseen: kasvatustieteellisen tutkimuksen ja teorianmuodostuksen historiaa. Turun yliopisto. Kasvatustieteiden laitoksen julkalsusarja A:67.

Päivänsalo, P. (1971). Kasvatuksen historian tutkimus Suomessa vuoteen 1970. Helsinki: ylioppilastuki.

Rinne, R. \& Kivirauma, J. (1997) (toim.) Suomalaisen kasvatustieteen historia - lyhyt oppimäärä. Turun yliopisto. Kasvatustieteiden laitos tutkimuksia A:182. 